\title{
Theories About Effects of Islamic Slaughter Laws on Meat Hygiene
}

\author{
Bahador Hajimohammadi ${ }^{1, *}$; Mohammad Hasan Ehrampoush ${ }^{2}$; Behrooz Hajimohammadi $^{3}$ \\ ${ }^{1}$ Department of Food Hygiene and Safety, Faculty of Health, Shahid Sadoughi University of Medical Sciences, Yazd, IR Iran \\ 2 Department of Environmental Health, Faculty of Health, Shahid Sadoughi University of Medical Sciences, Yazd, IR Iran \\ 3 Department of English Language and Literature, Gorgan Branch, Islamic Azad University, Gorgan, IR Iran \\ *Corresponding author: Bahador Hajimohammadi, Department of Food Hygiene and Safety, Faculty of Health, Shahid Sadoughi University of Medical Sciences, Yazd, IR Iran. Tel: \\ +98-9112751283, Fax: +98-3516238555, E-mail: hajimohammadi.b@ssu.ac.ir
}

Received: August 23, 2013; Revised: October 3, 2013; Accepted: October 23, 2013

Keywords: Islam; Abattoirs; Hygiene

\section{Introduction}

Meat is one of the most important foods in balanced diet of human beings. It is the main source of proteins with high biological value, vitamin $B$ and minerals particularly iron. It is stated that humans have been hunting animals and consuming meat since prehistoric times. Today, domestic animals such as cow, sheep, goat and camel are being slaughtered for using the meat in all over the world. In holy Quran and Hadith, there are some orders followed by Muslims. Hence, meat is authorized for consumption when it is Halal condition, meaning lawful and legal. In the present study, some theories about the effects of Islamic orders on hygiene of meat are discussed. By referring to Islamic sources, five important religious orders pertaining to animal slaughtering are obtained.

\section{Religious Orders}

\subsection{Prevent Pain and Agony for Animals Before Slaughtering}

According to Islamic laws, annoyance for animals before slaughtering is strictly prohibited (1). It is obvious that one of the most important purposes of this order is related to ethical issues. However, researchers have indicated that this issue is of importance from the viewpoint of meat hygiene as well. Sever and unusual environmental stimulants (such as beating, fearing, being in noisy environment, etc.) irritate animals, resulting in the release of a large amount of adrenalin to circulatory system. Consequently, glycogen sources in muscles are degraded before animal slaughtering. Therefore, due to the reduction of glycogen amount in muscles of live animal, perfect glycolysis and lactic acid production does not occur during rigor mortis. Hence, meat $\mathrm{pH}$ will be higher than the natural status, making the meat perishable because of the faster generation of spoiling microorganisms in higher $\mathrm{pH}(2-4)$.

\subsection{Accessibility of Animals to Drinking Water Before Slaughtering}

One of the most important issues in Islamic slaughtering method is accessibility of animals to drinking water before slaughtering (1). According to the previous research, it is confirmed that animals should have access to water freely before slaughtering. Because, drinking water reduces secondary microbial infection of animal carcass. On the other hand, after drinking enough water, infiltration of bacterial pathogens from intestine to muscles decreases the improvement in meat hygiene and safety. Electric shock is only permitted for stunning methods of Halal slaughtering provided the induction of direct electric current to animal head via two electrodes. It is known that electric shock is more effective on animals that drink some water. Although from scientific viewpoint, its mechanism is not clear yet. Furthermore, sufficient drinking not only helps animals reduce stress but also glycolysis causes the meat to be less perishable $(2,5)$.

\subsection{Avoid Slaughtering Animals in the Sight of Others}

According to religious literature, killing an animal in the sight of the others is abominable (1). It appears that this action causes them severe stress. As mentioned earlier, stress leads to decrease meat quality and safety via reduction of glycogenic source and unusual increasing in $\mathrm{pH}$ of muscles $(2,4)$. 


\subsection{Avoid Complete Cutting of Animal's Head During Bleeding}

In accord with Islamic orders, it is preferred to avoid complete cutting of animal's head during bleeding (1). Based on scientific evidences, natural bleeding time in domestic animals is about 5-6 minutes and during this period, $40 \%-60 \%$ of blood volume exits from the body. The rest of the blood remains mostly in viscera and vessels. If the head is cut completely while bleeding is not finished yet, heartthrob and blood flow will be stopped. Thus, blood dose not exit thoroughly and a condition occurred, called imperfect bleeding of carcass. Residual blood in muscles with $\mathrm{pH}$ of about 7, leads to the increase of muscle $\mathrm{pH}$ and consequently meat aw (activity water) raises. The two facts mentioned above (the rise of $\mathrm{pH}$ and activity water) result in proliferation of spoilage microorganisms in which cause spoilage of the meat $(4,5)$.

\subsection{Avoid Cutting Spinal Cord}

In Islamic religious laws, it is stated that spinal cord should not be cut (1). Now, according to scientific facts, it is clear that this subject may endanger meat safety due to probability of the existence of prion. Prion is the agent of a zoonose disease named bovine spongiform encephalopathy (BSE) or mad cow. Central nervous system especially spinal cord is the most important source of infection in animal body. The symptoms mainly include severe nervous disorders and hysteria. Prion is a protein with no acid nucleic. It is very resistant to pasteurization, sterilization and other heat processing of meat. Unnatural heat resistance of this agent makes it as one of the most hazardous and complicated zoonotic pathogens. Most of infected cases have been reported in England and Ireland. However, there is not such dangers in Islamic nations such as Iran (6). It seems that the main reason is related to the stunning methods of slaughtering animals at abattoirs. As mentioned before, electric shock is only permitted for stunning methods of Halal slaughtering. While in some non-Islamic countries, stunning with pistol is common. In this method, animals are stunned by infiltration of bullet into the head. Different studies indicated that this way may infect meat to nervous tissue particles, because nervous tissues may be diffused on carcass following penetrating of skull bones by bullet. On the other hand, infected particles of nervous tissue may be transferred via circulatory system into interior edible organs especially lung. Hence, as also mentioned before, there are some concerns about the role of pistol stunning in prevalence of BSE in non-Islamic countries on which there have been many reports published to date (7-10).

\section{Acknowledgements}

We would like to thank Mr Hafez Hajimohammadi for his kind help in revising the manuscript.

\section{Authors' Contribution}

Both Bahador Hajimohammadi and Mohammad Hasan Ehrampoush contributed to doing the literature review and writing the paper. Behrooz Hajimohammadi revised and edited the English manuscript.

\section{Financial Disclosure}

There are no conflicts of interest.

\section{Funding/Support}

There was no financial support.

\section{References}

1. Makarem Shirazi N. [Tozih-Al-Masael Resaleh]. Madrese-Imam-Ali: Qom; 2005.

2. Akhondzadeh Basti A, Hajimohammadi B. Principles of meat and abattoir hygiene. Tehran: University of Tehran Press; 2011.

3. Gracey JF, Collins DS, Huey RJ. Meat Hygiene. 10 ed. W.B. Saunders; 1999.

4. Lahucky R, Palanska O, Mojto J, Zaujec K, Huba J. Effect of preslaughter handling on muscle glycogen level and selected meat quality traits in beef. Meat Sci.1998;50(3):389-93.

5. Hui YH, Nip WK, Rogers R. Meat Science and Applications. Taylor \& Francis; 2001.

6. Meshkat M, Rokni N. Survey on BSE risk material in heat treated meat products (sausage) with ELISA test in Tehran. Pajouhesh \& Sazandegi. 2004;65:36-41.

7. Lim DG, Erwanto Y, Lee M. Comparison of stunning methods in the dissemination of central nervous system tissue on the beef carcass surface. Meat Sci. 2007;75(4):622-7.

8. Kingombe CI, Luthi E, Schlosser H, Howald D, Kuhn M, Jemmi T. A PCR-based test for species-specific determination of heat treatment conditions of animal meals as an effective prophylactic method for bovine spongiform encephalopathy. Meat Sci. 2001;57(1):35-41.

9. Wales C, Harvey M, Warde A. Recuperating from BSE: the shifting UK institutional basis for trust in food. Appetite. 2006;47(2):18795.

10. Dikeman M, Devine C, Devine C, Dikeman M, Jensen WK. Encyclopedia of Meat Sciences. Elsevier Science; 2004. 